\title{
Revista
}

Brasileira

de Enfermagem

REBEn

THEMATIC EDITION:

GOOD PRACTICES: FUNDAMENTALS OF

CARE IN GERONTOLOGICAL NURSING

RESEARCH

\section{Complex educational and care (geron)technology for elderly individuals/ families experiencing Alzheimer's disease}

\author{
(Geronto)tecnologia cuidativo-educacional complexa para pessoas idosas/famílias com a doença de Alzheimer \\ (Geronto)tecnología cuidadora-educacional compleja para personas ancianas/familias \\ con la enfermedad de Alzheimer
}

\section{Silomar Ilha', Silvana Sidney Costa Santos', Dirce Stein Backes", Edaiane Joana Lima Barros"II, Marlene Teda Pelzer', Regina Gema Santini Costenaro"}

' Universidade Federal de Rio Grande, Postgraduate Program in Nursing. Rio Grande, Rio Grande do Sul, Brazil. "Centro Universitário Franciscano, Biological Sciences and Health Area, Nursing Course. Santa Maria, Rio Grande do Sul, Brazil.

I"' Universidade Federal do Rio Grande, University Hospital Dr. Miguel Riet Corrêa Jr. Rio Grande, Rio Grande do Sul, Brazil.

\section{How to cite this article:}

Ilha S, Santos SSC, Backes DS, Barros EJL, Pelzer MT, Costenaro RGS. Complex educational and care (geron)technology for elderly individuals/families experiencing Alzheimer's disease. Rev Bras Enferm [Internet]. 2017;70(4):726-32. [Thematic Edition "Good Practices: Fundamentals of care in Gerontological Nursing"] DOI: http://dx.doi.org/10.1590/0034-7167-2016-0687

\section{Submission: 02-10-2017 Approval: 03-09-2017}

\section{ABSTRACT}

Objective: To describe the contributions of the Integrated Multidisciplinary Care Group for Caregivers of Individuals with Alzheimer's Disease as an educational and care (geron)technology in the context of Alzheimer's disease in elderly individuals from the perspective of family members/caregivers. Method: Exploratory, descriptive study with a qualitative approach conducted with 13 family members/ caregivers of elderly people participating in the support group of a university institution of the state of Rio Grande do Sul, Brazil. Data collected between January and April 2016 through a semi-structured interview were submitted to discursive textual analysis. Results: Family members/caregivers pointed out education and care as contributions of the group; education for care and for the future; exchange, socialization, and development of knowledge through the range of knowledge existing in the Group. Conclusion: The Group contributes as a (geron)technology of care and education for care in which knowledge is built and applied in practice, supporting the experienced disorders and improving the quality of care provided for elderly individuals with Alzheimer's disease.

Descriptors: Elderly; Alzheimer's disease; Technology; Nonlinear dynamics; Nursing.

\section{RESUMO}

Objetivo: Descrever as contribuições do Grupo de Assistência Multidisciplinar Integrada aos Cuidadores de Pessoas com a Doença de Alzheimer como (geronto)tecnologia cuidativo-educacional no contexto da doença de Alzheimer em pessoas idosas, na perspectiva de familiares/cuidadores. Método: Pesquisa exploratório-descritiva, qualitativa, realizada com 13 familiares/ cuidadores de pessoas idosas, participantes do grupo de apoio de uma instituição universitária do Rio Grande do Sul, Brasil. Os dados coletados entre janeiro a abril/2016, com uma entrevista semiestruturada, foram submetidos à análise textual discursiva. Resultados: Os familiares/cuidadores referiram como contribuições do Grupo a educação e o cuidado; a educação para o cuidado e para o futuro; a troca, socialização e construção do conhecimento por meio dos diversos saberes existentes no Grupo. Conclusão: O Grupo contribui como (geronto)tecnologia de cuidado e educação para o cuidado; nele, são construídos conhecimentos que, aplicados na prática, auxiliam nas desordens vivenciadas, melhorando o cuidado à pessoa idosa com doença de Alzheimer.

Descritores: Idoso; Doença de Alzheimer; Tecnologia; Dinâmica Não Linear; Enfermagem.

\section{RESUMEN}

Objetivo: Describir las contribuciones del Grupo de Atención Multidisciplinaria Integrada a Cuidadores de Personas con Enfermedad de Alzheimer como (geronto)tecnología cuidadora-educacional en el contexto de la Enfermedad de Alzheimer en ancianos, en la visión de familiares/cuidadores. Método: Investigación exploratorio-descriptiva, cualitativa, realizada con 13 familiares/cuidadores de ancianos, participantes del grupo de apoyo de una institución universitaria de Rio Grande do Sul, Brasil. Datos recolectados de enero a abril/2016, mediante entrevista semiestructurada, sometidos a análisis textual discursivo. Resultados: Los familiares/cuidadores mencionaron como contribuciones de Grupo la educación y el cuidado; la educación para el cuidado y para el futuro; el intercambio, 
socialización y construcción del conocimiento mediante los diversos saberes existentes en el Grupo. Conclusión: El Grupo contribuye como (geronto)tecnología de cuidado y educación para el cuidado; en él se construyen conocimientos que, aplicados en la práctica, colabora en los desórdenes experimentados, mejorando el cuidado al anciano con Enfermedad de Alzheimer.

Descriptores: Anciano; Enfermedad de Alzheimer; Tecnología; Dinámicas no Lineales; Enfermería.

\section{CORRESPONDING AUTHOR Silomar Ilha Email: silo_sm@hotmail.com}

\section{INTRODUCTION}

With the aging process the human being becomes susceptible to the emergence of chronic non-communicable diseases $(\mathrm{CNCD})^{(1)}$, particularly Alzheimer's disease (AD), which accounts for nearly $70 \%$ of the cases of dementia in elderly individuals ${ }^{(2)}$. There are currently more than 15 million individuals with $A D$ worldwide; in the United States of America there are 5.4 million people with this disease; of these, 5.2 million are aged over 65 years. By 2050, one individual will develop AD every 33 seconds ${ }^{(3)}$. In Brazil nearly 1.2 million people are affected by AD, although most of them are not yet diagnosed ${ }^{(4-5)}$.

In the daily care process directed toward elderly individuals with $\mathrm{AD}$, family members experience disorders generated by the disease that lead them to constant reorganizations in their functioning structure in order to maintain social interactions and care for the elderly. This reorganization implies the development of differentiated and adapted relational processes in order to live (and coexist) with the disease that may generate feelings of disorders, fear, insecurity, and gradual loss ${ }^{(6)}$.

Nurses have an important role in the family reorganization process, as they are the professionals responsible for the leadership and systematization of the care process for people in a range of different scenarios. The performance of nursing care requires an understanding of the human condition and its relations, which recursively depend on the environment and specificity of the human being that is under care or takes care of themselves ${ }^{(7)}$. Therefore it is difficult for a single professional to be able to develop the care in an extended, consistent way that addresses the individual/collective needs. There is a need for interdisciplinary and transdisciplinary professional approaches to support family members/caregivers in the singular, multidimensional, and complex daily care activities.

Observing the reality experienced by these family members and the importance of an integrated service in the context of gerontology, some professionals and health/teaching institutions have been investing efforts in the use of educational gerontechnologies in nursing care. Gerontechnologies consist of contributive technologies for the care for elderly people that take into account the aging process and the health/disease process, promoting care, co-responsibility, and co-participation ${ }^{(8)}$.

In this context the group for Integrated Multidisciplinary Care for Caregivers of Alzheimer's Disease Patients (AMICA) has developed comprehensive support for caregivers, discussing issues of their daily routine related to AD by means of the construction of knowledge among family members/caregivers, professors, and students in the courses of the health/ human areas: nursing; pharmacy; physiotherapy; nutrition; dentistry; psychology; and occupational therapy ${ }^{(9)}$.
The group is characterized as a complex environment consisting of development of knowledge, education, and care in the context of $\mathrm{AD}$ in elderly individuals by means of the multiple relations, interactions, and retroactions existing between professors and students and the family members/caregivers of elderly people with AD. Complexity is the union between the unit and the multiplicity of what has been woven together ${ }^{(10)}$. As elements of AMICA, each participant, whether family member, caregiver, professor, or student, is unique and at the same time inseparable and constitutive of the whole. There is also an interdependent, interactive, inter-retroactive web between all of the individuals involved and the care and (re)organizational context at AMICA.

AMICA represents a complex educational and care (geron) technology, as it facilitates the teaching-learning process on $A D$, enabling the development of skills and mediating the knowledge for the care of elderly people with AD. However it is necessary to investigate the perceptions of individuals that participate in this (geron)technology in order to identify its contribution in the context experienced by them, justifying the need for and relevance of this study, which may contribute to strengthen AMICA as a complex educational and care (geron)technology and enabling an expansion of the developed gerontechnologies.

In view of the above, this study questions: What is the contribution of AMICA as a complex care-educational (geron) technology in the context of $\mathrm{AD}$ in elderly people from the perspective of family members/caregivers? In an attempt to answer the question this study aimed to describe the contributions of AMICA as an educational and care (geron)technology in the context of $\mathrm{AD}$ in elderly people from the perspective of family members/caregivers.

\section{METHOD}

\section{Ethical aspects}

The present study was submitted to the Committee for Ethics in Research on Human Beings (CEP) through the Brazil Platform CEP/CONEP system. The first contact with the participants occurred only upon approval by the CEP. The ethical precepts related to research involving human beings were respected in accordance with Resolution 466/2012 of the Ministry of Health ${ }^{(11)}$. The project was approved by a research ethics committee. The anonymity of the participants was guaranteed; they were identified by the letter $\mathrm{F}$ (family member) followed by a number (F1, F2... F13).

\section{Theoretical framework and type of study}

This was an exploratory, descriptive study with a qualitative approach $^{(12)}$ presenting Edgar Morin's Complexity Theory as the guiding thread $^{(13)}$. The choice of the reference to complexity 
occurred from the possibility of thinking about the concepts without considering them as concluded and understanding the multidimensionality of the phenomena from the singularity and possible interactions, relations, and associations ${ }^{(13)}$. Therefore the reference to complexity was chosen to guide researchers and the researched individuals to reflect on new ways to articulate the uncertainties and disorders into new ways of (re)creating the methods to understand the phenomenon.

\section{Study setting}

This study was conducted with family members of elderly people with $A D$ that participate in a support group named AMICA, developed in a higher education institution in the state of Rio Grande do Sul, Brazil. This group began activities in 2007 through an interdisciplinary team consisting of professors and students in the courses of the health and human areas of the institution.

Criteria of inclusion in the study: being a family member/ caregiver of an elderly individual with AD; being registered in AMICA; and attending or having attended it for a minimum period of six months. This period of time was sufficient so that the participants have already interacted, acquired knowledge about AD, and understood the way AMICA works, enabling them to describe their experiences. Criteria of exclusion: family members/caregivers with whom contact was not possible as a result of having moved from the city; or whose address and telephone numbers were not updated in the records of the group AMICA. Individually invited during January 2016 through telephone contact duly authorized to the researchers by the coordinator of the group AMICA, this study consisted of 13 family members/caregivers with whom home visits were scheduled according to the date and time each participant was available.

\section{Data collection and organization}

Home visits were conducted between January and April 2016. The data collection was performed through the semi-structured interview technique based on the guiding questions: How is it for you to take care of an elderly individual with AD? Do you experience or have you ever experienced any difficulties in living with/providing care to an elderly individual with AD? Please explain. Do you consider the existence of potentialities/facilities in the care process and in living with individuals with AD? Please explain. What is the meaning of the group AMICA for you? Have you implemented any adaptations/strategies and/or created something to facilitate the care process for elderly individuals with AD and their families? The interviews were recorded through the use of an MP3 player and subsequently transcribed.

\section{Data analysis}

Data were processed based on the discursive textual analysis technique, organized from a recursive sequence of three components: unitarization; establishment of relations; and communication ${ }^{(14)}$. In the unitarization stage the researcher performed an in-depth analysis of the texts, breaking them down in order to reach units of meaning. This stage was conducted with intensity and depth. Then the researcher aimed to establish relations through the process of categorization, which led them to develop relations between the base units, combining and classifying them, bringing these unitary elements together in the formation of sets that combined nearby elements and resulted in category systems.

Thus, similar units of meaning were collected, generating several levels of analysis categories. During the communication, the researcher introduced the understandings achieved from the two previous foci. This stage consisted of the last element of the proposed cycle of analysis, resulting in metatexts composed of description and interpretation so that the set represented a way of theorizing the investigated phenomena ${ }^{(14)}$.

\section{RESULTS}

Of the 13, five were female and eight were male. Age ranged between 30 and 66 years. Regarding the degree of relationship with the elderly individual with AD, eight were sons/ daughters, two were grandchildren, and two were spouses/ partners; the time of providing care ranged between two and 14 years. Of these family members/caregivers, eight lived with the elderly individual and five lived in another domicile. Nine of the family members/caregivers alternated the act of providing care with other people, while three provided care on a full-time basis. Their time of participation in AMICA ranged between six months and 10 years. All of the participants were the primary caregivers of the elderly individuals with AD.

The analysis and interpretation of the data from the interviews conducted with the family members/caregivers during the home visits enabled the development of a category: AMICA as a complex educational and care (geron)technology: Contributions...; and four subcategories, as shown in Figure 1.

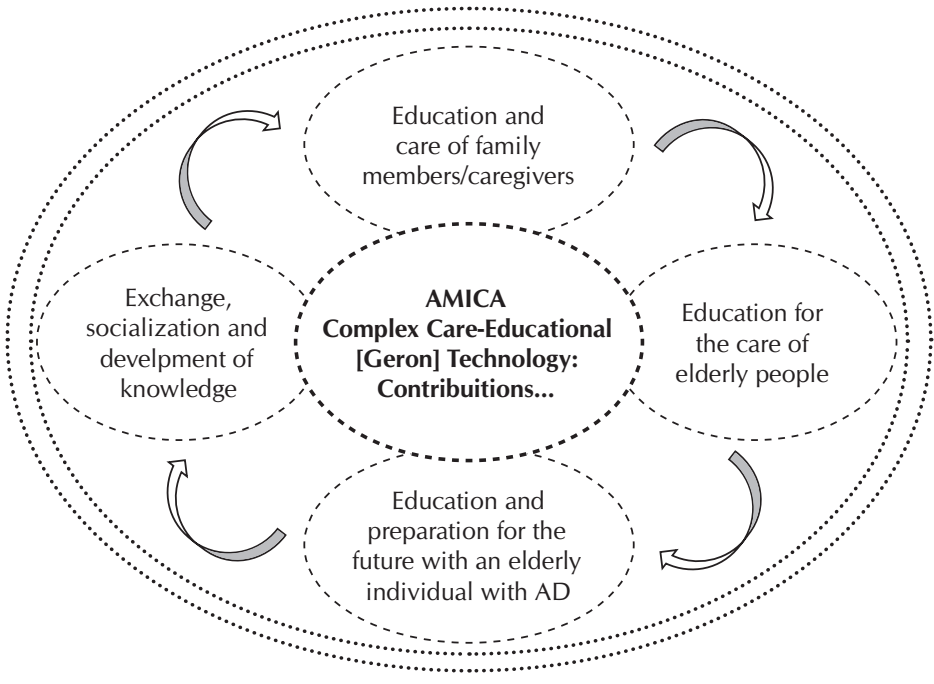

Note: AMICA refers to a support group named Multidisciplinary Support for Caregivers of People with Alzheimer's Disease; AD refers to Alzheimer's Disease.

Figure 1 - Complex demonstrative scheme of the (inter)connection of the category to the subcategories 


\section{Education and care of family members/caregivers of el- derly people}

This subcategory refers to the capacity of AMICA as a complex (geron)technology for the care and educational processes of family members/caregivers of elderly people with AD. The participants acknowledged this capacity of the group as they reported to have learned through participation in AMICA that it provides knowledge on $\mathrm{AD}$ and on how to provide care to elderly people. At the same time, they reported that they felt supported. It was observed that the care and educational processes are not static or fragmented; they occur at the same moment in the group:

In AMICA they provide a full teaching, a knowledge on the disease and how to provide care for individuals with $A D$; in addition, there is a comprehensive care in relation to us, to our emotional condition [...] only a group like AMICA is able to provide us all of this. There, at the same that I learned about the disease, I was also cared for by the group [...] there is no greater care than this one that I received there in AMICA; AMICA is something extraordinary [...] I have only managed to face everything because of the group; it provided all the support that prepared me and made me able to experience the daily routine with my mother in a natural manner; it taught me and supported me at the same time. (F1)

AMICA puts me in touch with people with distinct ideas and information; it enables this expansion and socialization of knowledge. Here in AMICA, in addition to learning, I also feel supported every time I come. When I go out I feel renewed. I can get here feeling bad, with my energies low, feeling a little exhausted, but when I arrive, everything is relieved; I go home feeling lighter, feeling really well. (F10)

Sometimes you arrive in the group feeling devastated, sad, and when you leave you feel relieved, happy. The group gives you strength to continue; we leave the place feeling full of ideas on how to improve the care. In AMICA there is a concern not only related to teaching about Alzheimer's but also in relation to care for ourselves, family members/ caregivers; there is a concern in relation to us. They take care of us; I always leave the place feeling better than when I arrived. I try to take care of myself in all aspects because today I am aware of how important this is. (F6)

The reports evidence the fact that the group AMICA instructs family members/caregivers in self-care, as they reported a higher level of care for themselves after their experience in the group. Some people also reported that they were feeling sad when they arrived, with their energy low, or even in pain, and that in the group these discomforts are relieved; they leave the place feeling better and lighter:

AMICA certainly prepares me to live better. Sometimes I arrive there feeling a lot of pain, sad, and when I leave the place I am feeling better [...] participating in the group is something that gives me pleasure; it gives me a spirit to live. In the group I learned and learn a lot about Alzheimer's and how to deal with people with this disease. In AMICA I feel cared for, I feel loved by the people that participate [...] if today I am more concerned about my health it is because I learned there that if I take care of my health I will live better. (F2)

[...] the group provides awareness to the family member/caregiver that they have to take care of themselves in order to be able to provide care. The group has been able to provide this understanding, this education for the care. Caregivers are those who really need care in order to be able to provide care and have a quality care. This focus of the group is very important; it provides care for family members/caregivers and instructs them beyond the care for people with $A D$. (F4)

In the following report it is possible to observe the circularity existing in the educational and care process in AMICA, as the participant reports that while they learn from professors and students, the family member/caregiver also teaches them; thus everyone learns from everyone. It is a recursive and dialogic process that occurs openly, allowing the input and output of knowledge from all sides. According to the family member/caregiver this also occurs with the care process in the group, as they report that everyone takes care of themselves, learns, and teaches every day in AMICA.

The group represents a very good support; it improved my self-esteem [...] In AMICA we feel supported, we feel free to talk, to discuss about our daily life. This dialogue that occurs openly between professors, students, and caregivers is very positive and makes me feel relaxed to talk about myself. At AMICA I feel that I learn a lot, but I can also teach a little about what I know about care; that's how it works, one learns from the other. What I am experiencing now has already been faced by other family members, or another family member will experience it, so this knowledge is shared among everyone. We take care of ourselves; we learn and teach every day in the group. (F9)

\section{Education for the care for elderly people from the experi- ences at AMICA}

This subcategory evidences the capacity of AMICA as a complex educational and care (geron)technology in the process of education for care of elderly people with AD. Family members/ caregivers explain that they learn at AMICA and that it provides knowledge on $\mathrm{AD}$ and how to provide care for elderly people so that they are able to improve their care practices:

[...] every time I come to the group I return home full of energy to take care of my husband with $A D$. I take from here all the necessary knowledge to improve the quality of care for him, because in AMICA I have already learned a lot about the ways of care, feeding, medication, on how to adapt the house, removing carpets, how to help him to brush his teeth, about how to cope with this disease without getting sick. It is about how to get through the hard days, living better with the individual with $A D$. I improved the quality of the care a lot after I started to attend. I am in love with this group! (F9)

The group is really very important in my life. At AMICA I found real support-guidance on the disease, on how to manage each situation with my mother at home-and this 
really improved the quality of the care I provide to her. I have already learned many things here [...] and everything I learn I try to teach to other people-my family, neighbors, and friends. (F10)

The report of family member/caregiver F9 presents some questions related to the care that caregivers learned at AMI$\mathrm{CA}$; it emphasizes the care in relation to feeding, medication, home adaptations, the importance of removing carpets, ways to help patients to brush their teeth, and how to live with an AD patient without getting sick. The report of F10 evidences that this knowledge about the care produced in the group is shared with other people that do not even attend the group, such as family members, neighbors, and friends.

\section{Education and preparation for the future with an elderly individual with Alzheimer's disease}

In addition to supporting family members/caregivers in the daily care for elderly individuals, this complex educational and care (geron)technology also instructs them in relation to what they will face. In other words, there is an educational and care process in the present and a preparation for the future:

[...] for me it was a preparation for the future, because in the group I was being prepared and I thought: Now this will happen; tomorrow that will happen. So in a certain way, this minimized a little the affliction resulted from living with someone with this disease. (F13)

[...] in the group I started to learn and I stopped being afraid. I faced every step, every new situation that emerged; I knew it was going to happen and then I was already aware of how to proceed. Who helped me, who prepared me for the future with the $A D$, even to my mother's death, was the group, was AMICA. So I have no words to explain everything this group represented in my life. (F1)

The report of $\mathrm{F} 1$ evidences that $\mathrm{AMICA}$ was present as an educational and care (geron)technology even at the moment of the death of the elderly family member with AD. The reports below evidence that the family members understand how the future with $A D$ will be, and that this preparation strengthens them to experience the processes that are yet to come:

[...] today I know what this disease is, and I know that things will get worse over time. After I started to attend the group my vision on the disease and care improved a lot [...] AMICA teaches me how to deal with the situations I face and that I will face on my way, and it prepares me for the future; it has really helped me [...] (F5)

[...] AMICA clarified many questions through the explanations by the professors and students as well as through the testimonies of other caregivers that had already experienced certain situations that I faced after some time, but it was different, because I already knew what I would face. The group prepares the individual for what they will find ahead. (F8)

After I started to participate in the group I no longer see Alzheimer's as rocket science, because I am together with the group seeking to understand and improve the quality of the care. The group helps me to be prepared for things that are yet to come $[\ldots]$ (F6)

As shown in the report of F6, the family member/caregiver, from their experience in AMICA, is no longer afraid of what they will face in their coexistence with and care for the elderly individual with $\mathrm{AD}$, as they no longer see care for the disease as "rocket science." This fact results from the educational and care process developed in the group, and the understanding of the disease and the possible ways of care.

\section{Exchange, socialization, and development of knowledge}

For family members/caregivers of elderly people, the greatest potential of AMICA as an educational and care (geron)technology is the capacity for exchange, socialization, and development of knowledge in a horizontal way among all of the participants, enabling the emergence of new knowledge developed collectively:

We learn a lot in the group through the exchange between our knowledge and the knowledge of students and professors [...] In the group there is no difference in the knowledge; it doesn't matter who knows more and who knows less. At AMICA the caregivers are there to learn, but also to bring their experiences and help other people; we are all respected and cared for in the group. (F2)

[...] the greatest wealth of the group is the exchange of experience among professors, students, and caregivers. The knowledge in the group is collective, and this is its strength, because the knowledge is built among the participants and at the same time everyone participating in the group is cared for as well [...]. (F4)

[...] Everyone that shows up here brings some knowledge, some teaching, and they also get a lot [...] This knowledge, this exchange that exists here is something extremely great, we cannot measure it; it brings together the theory by professors and students with the practice of the caregivers [...] The knowledge emerges in AMICA through the combination of practice with theory, through the union of all of the members of the group. (F10)

[...] we come to the group seeking information, knowledge, but we also bring our knowledge on the care practice, and together we build a greater knowledge that we subsequently transmit to other people in different places, whether at home or work, with friends, neighbors, and such. (F11)

\section{DISCUSSION}

In order to understand the complexity of the order-disorder-(re)organization phenomenon experienced by families that live with an elderly individual with $A D$ it is necessary to consider the meaning of being a family member/caregiver inserted into a complex context by their relations and interactions, as well as being exposed to order, disorder, and chaos. It is necessary to expand the focus beyond the disease and enter new paradigms in order to learn the meaning of the illness process in a multidimensional way ${ }^{(15)}$. 
The changes occurred in the lives of family members/caregivers trigger attitudes that change the environment all the time, whether to a new disorder or a new order. For Morin's Complexity Theory, disorder is inseparable from the universe, as it cooperates in the emergence of order. Therefore order and disorder are presented at the same time, as concurrent, complementary, and antagonistic ${ }^{(15)}$. Here, in this disorder process, AMICA emerges in the life of these people that precisely come aiming to understand the disorder experienced from the AD in their elderly family member. Consequently they find understanding and support in the process of (re)organization in order to improve their coexistence with and the care provided for the elderly individual.

Morin suggests that individuals should understand the contradiction and the unpredictable from the coexistence with AD patients. He emphasizes that the difficulty of complex thought is precisely related to facing the confusion, the uncertainty, and the contradiction without ceasing to live with the solidarity of the phenomena existing among themselves ${ }^{(13)}$. AMICA, as a complex educational and care (geron)technology, has this dimension; it approaches complex themes such as care and its uniqueness as something dynamic, circular, complementary.

Moreover, the group works in the context of AD in elderly individuals/family members requiring the transformation of the knowledge of complexity into a thought of complexity. In the case of a currently incurable disease it is not aimed at putting an end to the disorders generated by the condition, but at understanding them and developing ways of living with elderly individuals with AD. Therefore AMICA has been helping family members/caregivers to understand the order that emerges from the disorders experienced in daily life, enabling, in the investigated reality, a better quality of care for the elderly.

Family members/caregivers reported that AMICA provides education on AD and on how to provide care for elderly individuals; at the same time, they feel cared for and inspired to engage in self-care. In this context the circularity of the educational and care process in AMICA was observed. In this case they are not antagonistic processes; they are complementary, inseparable, and constitutive of the group. It is not possible to separate the care process and in the other the educational process in a given moment; both occur at all times in a circular, complementary, and complex way.

The described process occurs through the circularity and complementarity with which the knowledge is socialized and developed in the group by means of the (inter)connection of knowledge between professors, students, and family members/caregivers, referring to a complex thought that enables a visualization of the constitutive parts of the whole. This circularity that exists in the whole/parts and vice versa presents an interdependent, interactive, and inter-retroactive web in the sphere of the object of knowledge. That is, AMICA is a complex educational and care (geron)technology formed by the distinct knowledges that make it up: the parts and the whole; the whole and the parts; and the parts between themselves ${ }^{(10)}$.

For Morin, the whole is as important as its parts, and the parts are no more and no less than the whole ${ }^{(10)}$. It is understood that the several kinds of knowledge, whether scientific or a result of the experiences of family members/caregivers in the daily care routine, affect the whole, that is, the (geron)technology-AMICA, as a complex unit. This, in turn, goes back to the parts in a circular movement of complementarity, leading the participants to understand the moments of order and disorder, initially perceived as antagonistic, as motivators of (re)organizations.

AMICA as a care-educational (geron)technology needs to be understood as a complex unit formed by the union between the units and the multiplicities of what has been developed together. As elements of this (geron)technology, each one of the family members/caregivers, professors, and students represents an inseparable, constitutive part of the whole, that is, of AMICA as a unit.

When they go to AMICA, family members/caregivers sometimes feel tired, stressed, and sad as a result of the experienced reality with an elderly family member with $A D$, a fact that triggers new disorders and, consequently, (re)organizations. In this situation, AMICA as a complex educational and care (geron)technology is driven to help family members/caregivers in the development of strategies to support the understanding and coping processes aimed at an adaptation and (re)organization in view of the experienced situation ${ }^{(16)}$.

The chosen reference is highlighted as a potentiality of this study. It enabled an expansion of the understanding on the phenomenon and the understanding of AMICA as a (geron) technology with view toward describing their contributions to the daily life of the elderly individual/family member from the perspective of family members/caregivers. These factors attribute to this study characteristics that make it contributive to the innovation and rethinking of the activities developed in AMICA, strengthening it as a complex care-educational (geron)technology that generates new gerontechnologies of care for elderly individuals/family members with AD.

The importance of the work developed in AMICA as a complex (geron)technology regarding the care and education of family members/caregivers in self-care the and care for elderly individuals with $A D$, and in their preparation for the future with the elderly individual with AD, is emphasized. This understanding was built in the group, among other factors, by the perception of the individuals as unique and multidimensional beings, encompassing the family members/caregivers that are exposed to everyday order and disorder, conflicts, uncertainties and certainties, questionings, instabilities, and chaos, which in turn are able to be (re)organized from the behavioral disorders and uncertainties.

Therefore this study suggests that AMICA continues to be strengthened and that new gerontechnologies are built from it in order to support the family members/caregivers of elderly people in the daily care routine, subsidized by a new vision focused on the interdisciplinary approach. That is, it is a focus on the dialogue between the different knowledge of professors and students of courses of the area of health and family members/caregivers, aimed at a common objective: improving the quality of care and the health of elderly individuals with $\mathrm{AD}$ and their families.

\section{Limitations of the study}

Limitations of this study include the scarcity of bibliographies on technologies related to the theme of AD in elderly individuals and their families. It is also pointed out that only 
the data collected about the perception of the contribution of AMICA as an educational and care (geron)technology in the context of $\mathrm{AD}$ in elderly individuals with the group of family members/caregivers participating in AMICA were submitted to the recent article. The perceptions of professors and students that are also part of the group were not submitted.

\section{Contributions to the area of nursing/health}

The fact that the contributions of the group as an educational and care (geron)technology in the context of AD in elderly individuals are presented from the experience of family members/caregivers participating in AMICA is highlighted as a contribution of this study. This fact may contribute so that other professionals in the area of nursing/health are motivated to develop different therapeutic spaces to help family members and caregivers in the care process.

\section{FINAL CONSIDERATIONS}

The results enabled the descriptions of the contributions of AMICA as an educational and care (geron)technology in the context of Alzheimer's disease in elderly people from the perspective of family members/caregivers. They pointed to education and care of family members/caregivers of elderly people with $\mathrm{AD}$ among the contributions of AMICA-education for care and for the future of elderly people with $\mathrm{AD}$; and the exchange, socialization, and development of knowledge through the range of knowledge existing in the group. Therefore it is observed that AMICA contributes as a care and education resource for care (geron)technology, as some knowledge is built in it and, when applied, helps in the experienced disorders, allowing a new order from the (re)organization processes, thus affecting the care for the elderly individual with AD.

\section{REFERENCES}

1. Talmelli LFS, Vale FAC, Gratão ACM, Kusumota L, Rodrigues RAP. Alzheimer's disease: functional decline and stage of dementia. Acta Paul Enferm [Internet]. 2013 [cited 2016 Oct 05];26(3):219-25. Available from: http://www.scielo.br/pdf/ape/v26n3/en_03. pdf

2. World Health Organization (WHO). Dementia: a public health priority [Internet]. Geneva: WHO. 2012 [cited 2014 Dec 10]. Available from: http://whqlibdoc.who.int/publications/2012/9789241564458_eng.pdf

3. Alzheimer Association. Alzheimer's Disease Facts and Figures [Internet]. 2015 [cited 2016 Oct 05];11(3):332-384. Available from: https://www.alz.org/facts/downloads/facts_figures_2015.pdf

4. Associação brasileira de Alzheimer (ABRAz). Doença de Alzheimer: "Alzheimer: quanto antes souber, mais tempo você terá para lembrar" [Internet]. Brasil: Associação Brasileira de Alzheimer; 2012 [cited 2016 Oct 05]. Available from: http://abraz.org.br/ abraz-na-midia/release-institucional-doenca-de-alzheimer

5. Instituto Brasileiro de Geografia e Estatística (IBGE). Censo demográfico 2010: características da população e dos domicílios resultados do universo. Rio de Janeiro: IBGE, 2011.

6. Barros EJL, Santos SSC, Gomes GC, Erdmann AL, Pelzer MT, Gauterio DP. [Ecosystemic and gerontotechnological actions in complex nursing care to the elderly with ostomy]. Rev Bras Enferm [Internet]. 2014 [cited 2016 Oct 05];67(1):91-6. Available from: http://www.scielo.br/pdf/reben/v67n1/0034-7167-reben-67-01-0091.pdf Portuguese.

7. Cassola TP, Backes DS, Ilha S, Souza MHT, Cáceres KF. Adaptive process of caregivers of a person elderly with Alzheimer: contributions of nursing. J Nurs UFPE [Internet]. 2014 [cited 2015 Jul 15]; 8(Suppl. 1):2243-8. Available from: http://www.revista. ufpe.br/revistaenfermagem/index.php/revista/article/viewFile/5319/pdf 5622

8. Barros EJL, Santos SSC, Gomes GC, Erdmann AL. [Educational geronto-technology for ostomized seniors from a complexity perspective]. Rev Gaúcha Enferm [Internet]. 2012 [cited 2015 Jul 15];33(2):95-101. Available from: http://www.scielo.br/pdf/ rgenf/v33n2/14.pdf Portuguese.

9. Ilha S, Zamberlan C, Gehlen MH, Dias MV, Nicola GDO, Backes DS. Qualidade de vida do familiar cuidador de idosos com Alzheimer: contribuição de um projeto de extensão. Cogitare Enferm [Internet]. 2012 [cited 2015 Jul 15];17(2)270-6. Available from: http://revistas.ufpr.br/cogitare/article/view/27876/18481

10. Morin E. A Cabeça bem-feita: repensar a reforma, reformar o pensamento. 17ª ed. Rio de Janeiro: Bertrand Brasil; 2010.

11. Brasil. Conselho Nacional de Saúde. Diretrizes e normas regulamentadoras de pesquisa em seres humanos. Resolução $n^{\circ} 466$, de 12 de dezembro de 2012.

12. Lacerda MR, Costenaro RGS. Metodologias da pesquisa para a enfermagem e saúde: da teoria a prática. Porto Alegre: Moriá; 2015.

13. Morin E. Introdução ao pensamento complexo. 5a. ed. Lisboa: Instituto Piaget, 2008.

14. Moraes R, Galiazzi M.C. Análise textual discursiva. 2a ed. Ijuí: Editora Unijuí, 2011.

15. Ilha S, Zamberlan C, Piexak DR, Backes MTS, Dias MV, Backes DS. Contributions of a group about the Alzheimer's disease for family members/caregivers, professors and students from the healthcare field. J Nurs UFPE [Internet]. 2013 [cited 2015 Jul 15];7(4):1279-85. Available from: http://www.revista.ufpe.br/revistaenfermagem/index.php/revista/article/view/3967/pdf_2468

16. Seima MD, Lenardt MH. A sobrecarga do cuidador familiar de idoso com Alzheimer. Texto Contextos [Internet]. 2011 [cited 2015 Jul 15];10(2):388-98. Available from: http://revistaseletronicas.pucrs.br/ojs/index.php/fass/article/view/9901/7341 